\title{
APPLICATION OF NON-STANDARD DOE AND ITS VALIDATION IN DETERMINING NOMINAL PARAMETERS IN PRODUCTION PROCESS
}

\author{
Anastasija Ignjatovska, Mite Tomov \\ Faculty of Mechanical Engineering, "Ss. Cyril and Methodius" University in Skopje, \\ P.O. Box 464, MK-1001 Skopje, Republic of North Macedonia \\ aneignjatovska@yahoo.com
}

\begin{abstract}
A b s t r a c t: A structured approach is fundamental in designing a complex multivariable process, while achieving specified product quality. Nominal values of process parameters of an injection molding process are defined by implementing DOE methodology. Optimisation of experimental phase is achieved by progressive information acquiring concerning influential input factors and DOE design. Hence, most influential machine process parameters are varied using a non-standard fraction-factorial design. A linear regression model with included elements of second order interaction is defined based on obtained data. Additional testing of its validation is in order before reaching a final conclusion. Firstly, model significance is tested by conducting an ANOVA analysis. Only significant models prove that DOE has been adequately planned and factors which affect the controlled output have been chosen. Finally, DOE is completed by adequacy analysis of the regression model. Lack-of-fit test is chosen to test whether the model is a proper representation of the real process.
\end{abstract}

Key words: design of experiments; non-standard fraction-factorial design; injection molding; model validation

\section{ПРИМЕНА НА НЕСТАНДАРДЕН ФОЕ И НЕГОВА ВАЛИДАЦИЈА ЗА ДЕФИНИРАЊЕ НА НОМИНАЛНИ ВРЕДНОСТИ НА ВЛЕЗНИ ПАРАМЕТРИ ЗА ПРОИЗВОДСТВЕН ПРОЦЕС}

\begin{abstract}
А п с т р а к т: При дизајнирање на комплексен производен процес кој зависи од голем број влезни варијабли, кој треба да се карактеризира со одредено ниво на квалитет, неопходна е примена на структуиран пристап. Во овој труд, DOE методот е искористен за дефинирање на номиналните вредности на влезните процесни параметри за процес на инјекционо вбризгување. Користејќи ги прогресивно стекнатите сознанија за процесот во врска со највлијателните влезни фактори и соодветниот DOE дизајн кој би се искористил, извршена е оптимизација на експерименталната фаза. Следствено, при изведба на експериментот, извршена е варијација само на највлијателните влезни фактори, користејќ нестандарден скратен факторен дизајн. Врз база на експериментално стекнатите податоци генериран е линеарен регресивен модел со членови на интеракција од втор ред. Пред да се донесе финален заклучок, направени се дополнителни анализи за валидација на моделот. Најпрво, преку АНОВА анализа тестирана е значајноста на регресивниот модел. Само значаен модел потврдува дека фазата на планирање на DOE била исправно извршена и избраните влезни фактори предизвикуваат варијација на контролираниот одзив. Конечно, DOE е комплетиран со анализа на адекватност на моделот. Lack-of-fit тестот покажува дали моделот реално ги претставува експериментално стекнатите податоци.
\end{abstract}

Клучни зборови: дизајн на експерименти; нестандарден скратен факторен дизајн; инјекционо вбрзигување; валидација на модел.

\section{INTRODUCTION}

Implementation of design of experiments (DOE) methodology at the earliest, trial stages of the development cycle of a new process, sets a solid foundation for productive and quality serial production process. This especially applies to multivariable production processes where part quality varies due to various controlled and uncontrolled factors.
The essence of DOE is its planning phase. Only properly planned DOE leads to efficient experiment and applicable data. Ideal planning phase of DOE would result in minimal number of experimental iterations, while including all influential input factors and minimizing the experimental error. Consequently, relevant data would be collected and analysed by statistical methods which would enable development of a reliable model-based process. 
A method to determine the minimal number of experimental iterations was proposed by MKS [1]. The study presents that fractional factorial model shows approximately same results as full factorial model. Ten input factors are varied. In practise this would cause decrease of experiment efficiency. Also, experimental error could not be estimated because experiment repetition is not included.

Crucial part of the planning phase is choice of input factors and their levels. Moreover, significance of collected data is directly predetermined by the selected DOE design. In order to simplify planning of DOE, Andrisano et al [2] propose an algorithm which determines optimal set of process parameters for given product requirements. However, method which determines proper DOE design is not included. S. Rajalingam et al [3] use three input factors with repetition. Abohashima et al [4] use four input factors with repetition to determine the influence of chosen factors on attributive characteristics. Both use a full factorial design. Effects of factors are calculated and plotted in Minitab software, but models are not defined.

After experiment performance, data analysis is in order. Statistical methods are used in transforming gained data into useful information. Output of DOE is a regressive model which represents the real process and identifies change in controlled parameter caused by variation of input factors. V. García et al [5] predict product quality in a tubing extrusion process using a regression model. The data set is obtained from a manufacturing company, collected among a longer production period. One of the many benefits of using DOE methodology is that relevant data set could be collected in only a few hours. Choice of optimal type of a regression model depends on the nature of the process itself. Pan et al [6] present comparison between different types of regression models. Kulkarni [7] shows that a linear regression model which involves first-order interaction members is the most adequate one to describe an injection molding process.

Review of relevant literature shows that while individual stages of DOE are analyzed in detail, elaborated study of all stages used in solving a practical problem is not included. Proposed paper uses detailed analysis of all DOE stages in order to determine nominal values of process parameters of an injection molding process. Furthermore, it uses a non-standard DOE design which increases efficiency of the experimental phase, while including the effect of all influential factors. Based on acquired data, a linear regression model which involves first- order interaction members is defined. Prior to final acceptance of the regression model, additional analyses for its validation are conducted. Firstly, model significance is conducted through ANOVA analysis. ANOVA decomposes total variance into variability occurred under the influence of controlled factors and uncontrolled (residual) factors [8]. Only if a model proves to be significant, one may accept obtained data set of the experimental phase and continue further analysis. Finally, DOE is completed by conducting an analysis of adequacy of the regression model. Lack-of-fit test is used to test whether the model is a proper representation of the real process and collected data. Additionally, an Excel template has been developed for simple and fast future analysis of the any generated data set from DOE. A standard statistical software performs black-box calculations and only generates required output data. Using the proposed template, all the user would have to do is input the collected data and a mathematical model would be generated. Its significance and adequacy are tested as well, and results are printed instantly on screen.

\section{METHODOLOGY}

A case study is analysed. The flow of activities is shown in Figure 1. The purposes of this study are:

1. examination of correlation between the input machine process parameters of an injection molding process and critical for assembly dimension of a molded part

2. performing an efficient DOE

3. defining a regression model

4. validation of planning phase of DOE

5 . validation of the regression model

6. defining nominal values for the injection molding production process.

While variable characteristics of the molded part are the controlled output, attributive characteristics must not be impaired.

An alternative approach concerning choice of DOE design is proposed. Therefore, the experimental part of this study case is performed in two phases. The first phase examines influence of six factors at two levels using a standard full factorial DOE design. Input factors and their levels have been selected based on empirical experience and research [8]. Factor effects are estimated and only the most influential ones are used as input factors in phase 2 of the experimental stage. 


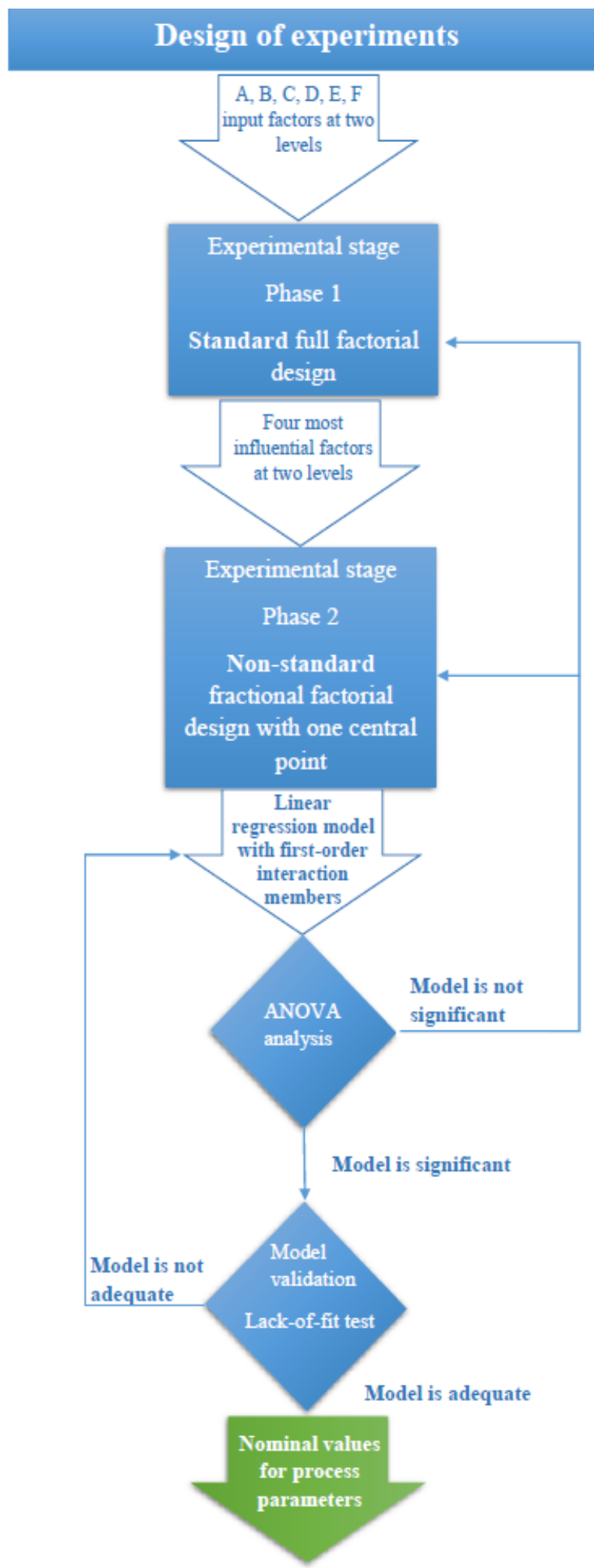

Fig. 1. Algorithm of activities for the case study acquired data of the performed experiment, a linear regression model with included elements of second-order interaction is defined

Four factors are varied using a non-standard fractional-factorial DOE design with one central point. Based on DOE could be completed only if validation tests are satisfied. Firstly, ANOVA analysis is carried out. ANOVA makes a direct comparison between the estimated change in the output due to variation of the controlled input factors and change in the output as a result to experimental error. Basically, variations between formed groups in DOE and within groups are compared. In this paper, ANOVA is used to test whether appropriate DOE design and factors have been chosen in the planning phase of DOE. Consequently, two hypotheses are set:

$H_{0}: \mu_{1}=\mu_{2}=\mu_{3}$ mean values of individual groups are statistically equal.

$H_{\mathrm{A}}$ : at least two individual groups have different mean values.

If the null hypothesis were to be met, it could be concluded that the change of the controlled factors does not affect the variation of the analyzed response. The change of the output is caused by uncontrolled factors. The collected data set is not statistically significant due to improper DOE design or choice of factors. Experimental phase would have to be repeated, using different design and/or factors.

On the other hand, if the alternative hypothesis were to be accepted, the variations of the input factors affect the variation of the controlled response. This proves significance of the regression model. It could be concluded that planing phase of DOE was properly done, concerning chosen design, factors and their levels. Once ANOVA test is fullfilled, DOE could proceed forward.

That one may properly complete DOE, validation test of the regression model has to be fullfilled. Fisher's lack-of-fit test is conducted in order to determine significance of non-conformity error. Basically, the test shows whether the regression model is a true representation of the collected data set of DOE. Therefore, again, two hypotheses are set:

$H_{0}$ : there is no significant lack-of-fit.

$H_{A}$ : there is a significant lack-of-fit.

If the null hypothesis were to be fullfilled, the regression model could be accepted as adequate, because there is not a significant non-conformity error due to lack-of-fit. DOE could be completed and the model could be used in solving the main problem. Nominal values for process parameters could be deteremined using the defined regression model.

If the alternative hypothesis were to be met, the regression model is not adequate. There may be some influential factors whose effect had not been taken into account. Changes in the regression model are in order. 


\section{DESIGN OF EXPERIMENSTS (DOE)}

\section{A. Planning phase of DOE}

Prior to experiment realization, all stages of its planning phase have to be properly completed. Input factors and their levels are chosen based on reviewed literature and past experience concerning the nature of the process, used granule and geometry of the molded part. The controlled output is a linear dimension specified in the technical documentation of the part, and its value is $209 \pm 0.46 \mathrm{~mm}$.

Choice of DOE design is fundamental in developing an efficient experiment and collecting relevant data. There are various types of experimental design. Most commonly used, one in DOE is factorial design, because it the only type of experimental design that can detect the effect of mutual interaction of factors [9]. Most experiments require analysis of the effects of several factors at the same time. All types of factorial designs can be divided in two large groups:

- standard DOE design or full factorial design

- non-standard DOE design or fraction-factorial design.

Standard DOE design can be defined as an experiment which investigates all possible combinations of factors. Table 1 shows a general experimental matrix for full factorial design with two factors A (a levels) and B (b levels).

First part of experimental phase is performed according to full factorial design. Based on research and experience, six most influential machine process parameters (Table 2) are chosen and varied within their process window.

There are up to four process parameters that will cause a significant variation in dimensions of a molded part [7]. Having in mind that practical and efficient DOE is one of the purposes of this study case, while enough replications to minimize the experimental error are performed, it is necessary to select only the most influential factors and vary them. In order to determine the four most influential process parameters, a full factorial $2^{6}$ standard design of DOE is performed and obtained data set is analyzed using a statistical tool - Tornado diagram (Figure 2).

A total of $2^{6}=64\left(2^{k}, 2-\right.$ number of levels for each factor, $k$ - number of factors varied) combinations of the experiment were performed, without repetition. Temperature of molten plastic (E) and screw speed (F) are omitted in further analysis, because full factorial DOE proved them to be factors with lowest influence.

Table 1

\section{General experimental matrix for full factorial design}

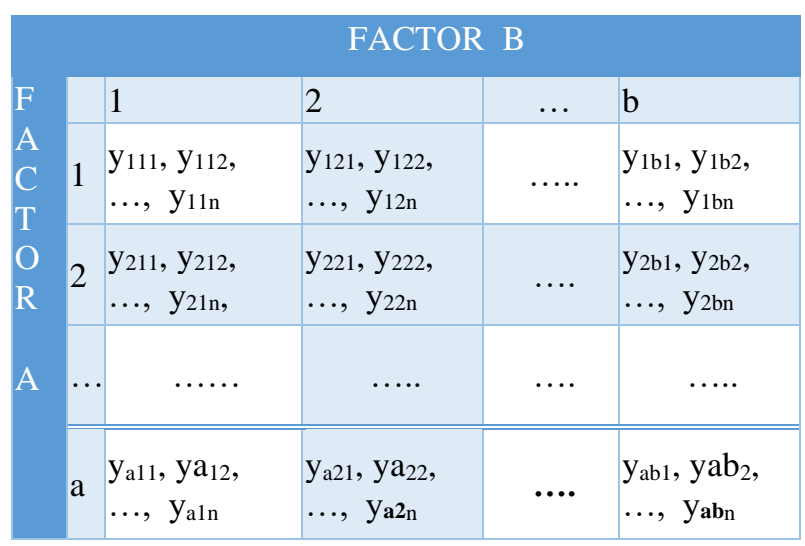

Table 2

High and low levels of input parameters

\begin{tabular}{|l|c|c|}
\hline \hline & \multicolumn{2}{c}{ LEVELS } \\
\hline \multicolumn{1}{l|}{ PARAMETER } & - & + \\
\hline \hline A: Mold temperature $\left({ }^{\circ} \mathrm{C}\right)$ & 50 & 90 \\
B: Injection speed $\left(\mathrm{cm}^{3} / \mathrm{s}\right)$ & 25 & 100 \\
C: Pressure (bar) & 400 & 800 \\
D: Cooling time (s) & 5.5 & 15 \\
E: Temperature of molten plastic $\left({ }^{\circ} \mathrm{C}\right)$ & 250 & 280 \\
F: Screw speed (upm) & 90 & 120 \\
\hline \hline
\end{tabular}

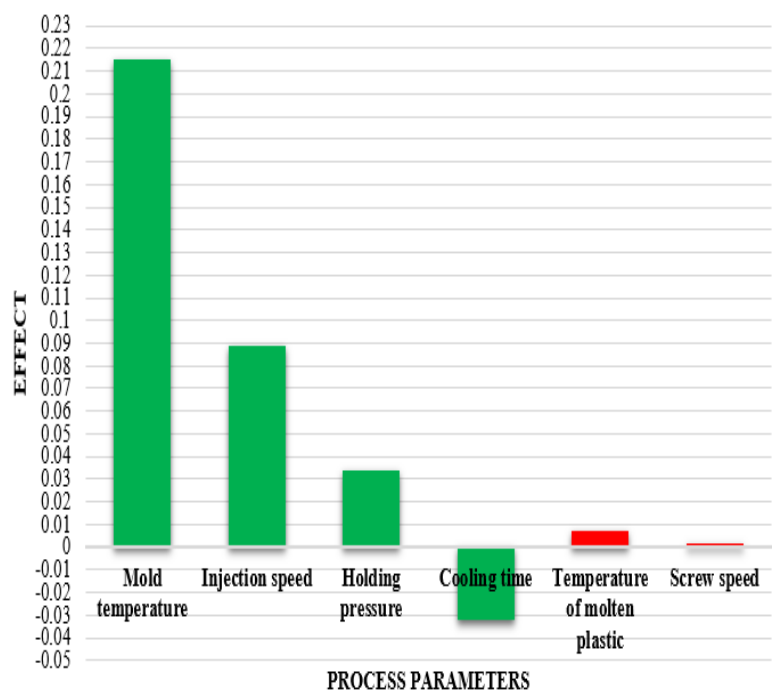

Fig. 2. Tornado diagram 
Consequently, in the second phase of the experimental part, only four factors are varied. If full factorial design were to be chosen again, $2^{4}=16$ combinations of the experiment (Figure 3) would have to be performed, without repetition. By increasing number of repetitions, experimental error is minimized. However, experiment efficiency decreases.

\begin{tabular}{ccccccccccccccccc} 
& & $A$ & $B$ & $A B$ & $C$ & $A C$ & $B C$ & $A B C$ & $D$ & $A D$ & $B D$ & $A B D$ & $C D$ & $A C D$ & $B C D$ & $A B C D$ \\
\hline 1 & $(1)$ & - & - & + & - & + & + & - & - & + & + & - & + & - & - & + \\
2 & $a$ & + & - & - & - & - & + & + & - & - & + & + & + & + & - & - \\
3 & $b$ & - & + & - & - & + & - & + & - & + & - & + & + & - & + & - \\
4 & $a b$ & + & + & + & - & - & - & - & - & - & - & - & + & + & + & + \\
5 & $c$ & - & - & + & + & - & - & + & - & + & + & - & - & + & + & - \\
6 & $a c$ & + & - & - & + & + & - & - & - & - & + & - & - & + & + & + \\
7 & $b c$ & - & + & - & + & - & + & - & - & + & - & + & - & - & + & + \\
8 & $a b c$ & + & + & + & + & + & + & + & - & - & - & + & - & + & - & + \\
9 & $d$ & - & - & + & - & + & + & - & + & - & - & - & - & - & - & - \\
10 & $a d$ & + & - & - & - & - & + & + & + & + & - & - & - & + & + & - \\
11 & $b d$ & - & + & - & - & + & - & + & + & - & + & - & - & - & + & + \\
12 & $a b d$ & + & + & + & - & - & - & - & + & + & + & + & - & - & - & + \\
13 & $c d$ & - & - & + & + & - & - & + & + & - & - & + & + & - & - & - \\
14 & $a c d$ & + & - & - & + & + & - & - & + & + & - & - & + & - & - & + \\
15 & $b c d$ & - & + & - & + & - & + & - & + & - & + & - & + & - & + & - \\
16 & $a b c d$ & + & + & + & + & + & + & + & + & + & + & + & + & + & + & +
\end{tabular}

Fig. 3. Experimental matrix for full factorial $2^{4}$ design

If certain high-order interactions between factors are assumed to be negligible, which can be deduced for injection molding process from reviewed literature [7], alternative approach might prove to be useful. Second part of the experiment is performed by varying A-D factors, using a non-standard fractional factorial design. Fractional factorial design omits part of experimental combinations. For example, $2^{4-1}$ (Figure 4) omits one half of the experimental combinations that a suitable full factorial design has. In order to estimate the experimental error, for each combination of values the experiment was repeated 10 times. A fractional factorial design with one central point has been chosen and a total of $\left(2^{4-}\right.$ $\left.{ }^{1}+1\right) \cdot 10=90$ parts have been molded. If full factorial design were to be used, a total of 170 parts would have to be molded.

\begin{tabular}{lllllllll} 
& $I$ & $A$ & $B$ & $C$ & $A B$ & $A C$ & $B C$ & $A B C$ \\
\hline$a$ & + & + & - & - & - & - & + & + \\
$b$ & + & - & + & - & - & + & - & + \\
$c$ & + & - & - & + & + & - & - & + \\
$a b c$ & + & + & + & + & + & + & + & + \\
$a b$ & + & + & + & - & + & - & - & - \\
$a c$ & + & + & - & + & - & + & - & - \\
$b c$ & + & - & + & + & - & - & + & - \\
$(1)$ & + & - & - & - & + & + & + & -
\end{tabular}

Fig. 4. Experimental matrix for fractional factorial $2^{4-1}$ design

\section{B. Regression model}

Once the experiment is completed and data set is collected according to factorial design, a regression model can be created. Considering nature of injection molding process, high-order interactions could be assumed negligible. That said, linear regression model has showed as most adequate to describe such processes $[7,9]$. In a general case, the input factor on $i j$ position of the experimental matrix shown in Table 1, in the $k$ replication of the experiment, would result in a $y_{i j k}$ response, which could be analytically determined by the following linear model:

$$
y_{i j}=\mu+\tau i+\beta j+(\tau \beta) i j+\varepsilon_{i j k}\left\{\begin{array}{l}
i=1,2, \ldots a \\
j=1,2, \ldots b \\
k=1,2, \ldots n
\end{array}\right\}
$$

where is:

$$
\begin{aligned}
& \mu \text {-total mean effect of the factors, } \\
& \tau_{i} \text { - effect of the } i \text {-level of factor A, } \\
& \beta_{i} \text { - effect of the } j \text {-level of factor B, }
\end{aligned}
$$

$(\tau \beta)_{i j}$ - effect due to interaction of $i$-level of factor A and $j$-level of factor B,

$$
E_{i j} \text { - experimental error. }
$$

General form of regression model for $2^{4} \mathrm{DOE}$ is [7]:

$$
\begin{aligned}
y & =\beta_{0}+\beta_{1} x_{1}+\beta_{2} x_{2}+\beta_{3} x_{3}+\beta_{4} x_{4}+\beta_{12} x_{1} x_{2}+\beta_{13} x_{1} x_{3}+ \\
& +\beta_{14} x_{1} x_{4}+\beta_{23} x_{2} x_{3}+\beta_{24} x_{2} x_{4}+\beta_{34} x_{3} x_{4}+\varepsilon
\end{aligned}
$$

There are some terms that can be omitted as negligible compared to the others. The error would be insignificants and the model would be much simpler. Therefore, a Pareto diagram is plotted based on collected data. As Figure 5 shows, the proposed model could be simplified as follows:

$y=\beta_{0}+\beta_{1} x_{1}+\beta_{2} x_{2}+\beta_{3} x_{3}+\beta_{4} x_{4}+\beta_{12} x_{1} x_{2}+\beta_{14} x_{1} x_{4}+\varepsilon$.

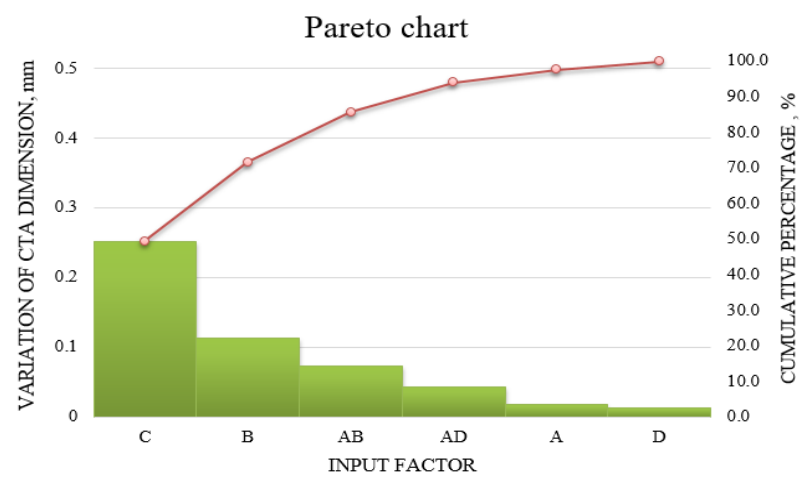

Fig. 5. Pareto chart

Values of cofficients expressing factor effect are calculated and shown in Table 3.

Finally, regression model is:

$$
\begin{aligned}
y= & 201.765-0.009 x_{1}+0.0565 x_{2}+0.1255 x_{3}+ \\
& +0.0060 x_{4}-0.036 x_{1} x_{2}+0.021 x_{1} x_{4}
\end{aligned}
$$


T a b le 3

Values of coefficients of factor effect

\begin{tabular}{c|c|}
\hline \hline $\mathrm{y}_{0}$ & 201.765 \\
\hline$\beta_{1}$ & -0.009 \\
\hline$\beta_{2}$ & 0.056 \\
\hline$\beta_{3}$ & 0.125 \\
\hline$\beta_{4}$ & 0.006 \\
$\beta_{12}$ & -0.036 \\
\hline$\beta_{14}$ & 0.021 \\
\hline \hline
\end{tabular}

\section{Validation}

Prior to final acceptance of the model, additional validation analyses are in order. Firstly, ANOVA analysis is conducted, which decomposes total variance into variability occurred due to effect of controlled factors and uncontrolled (residual) factors. The experiment satisfies all necessary assumptions for carrying out an ANOVA analysis:

- all measured values have to be normally distributed (concluded from plotted histogram shown in Figure 6),

- equal variances (or standard deviation values) among groups (a Cochran's test for group variance has been conducted and the condition has been met),

- random sampling.

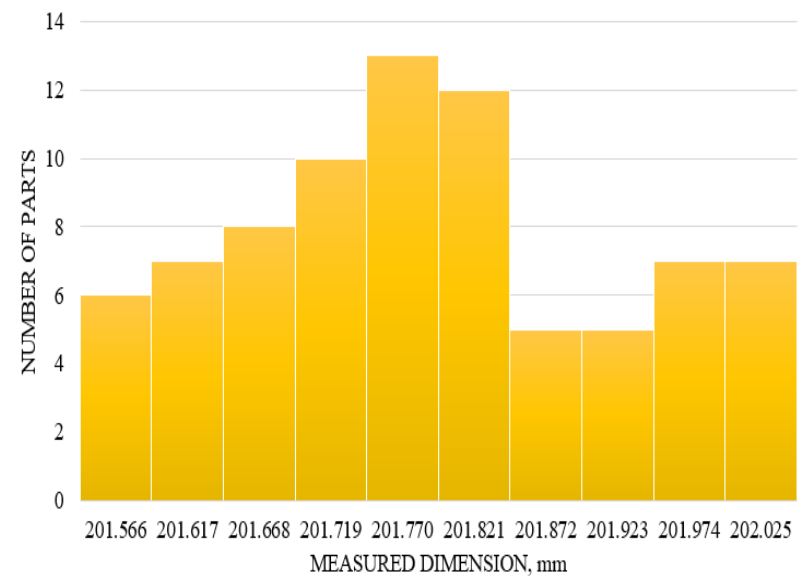

Fig. 6. Histogram of collected data set

Hence, one-way ANOVA can be performed.

Total variation or total sum of squares can be calculated:

$$
S S T=\sum_{j=1}^{k} \sum_{i=1}^{n}\left(y_{i j}-\bar{y}\right)^{2}
$$

where is: $n$ - number of experiment combinations with various values of input factors

$k$ - number of experiment repetitions with certain constant values of input factors

$$
\begin{aligned}
& y_{i j-} \text { - value of response } \\
& \bar{y} \text { - mean value of the response }
\end{aligned}
$$

This variation can be divided into two parts:

$$
S S T=S S G+S S E
$$

SSG - sum of squares group shows variation between different groups, formed by different combinations of input factors:

$$
S S G=\sum_{j=1}^{k}\left(\bar{y}_{\mathrm{j}}-\bar{y}\right)^{2}
$$

SSE - sum of squared estimate of errors shows variation within a group after experiment repetition with constant values of input factors:

$$
S S E=\sum_{j=1}^{k} \sum_{i=1}^{n}\left(y_{i j}-\bar{y}_{\mathrm{j}}\right)^{2}
$$

\begin{tabular}{|c|c|c|c|c|}
\hline Variation & Parameter & $\begin{array}{l}\text { Degrees of } \\
\text { freedom }\end{array}$ & Mean squares & $F_{p}$ \\
\hline $\begin{array}{l}\text { Between } \\
\text { groups }\end{array}$ & SSG & $\mathrm{k}-1$ & $M S G=\frac{S S G}{k-1}$ & $M S G$ \\
\hline $\begin{array}{l}\text { Among a } \\
\text { group }\end{array}$ & SSE & $\mathrm{n}-\mathrm{k}$ & $M S E=\frac{S S E}{n-k}$ & $M S E$ \\
\hline Total & SST & $n-1$ & & \\
\hline
\end{tabular}

$\bar{y}_{j}-$ mean value of the response of $j$ combination of factors.

Ta ble 4

ANOVA table for calculation of $F_{p}$

If the following condition were to be fulfilled:

$$
F_{p} \leq F_{t a b}
$$

null hypothesis would have to be accepted. Mean values of individual groups are statistically equal. It could be concluded that the change of the controlled factors does not affect the variation of the analyzed response. Planning phase of DOE would have to be performed again and certain correction would have to be done. Different design and/or input factor would have to be used.

On the contrary, if the following condition were to be met:

$$
F_{p}>F_{t a b}
$$


null hypothesis would have to be rejected. At least two individual groups have different mean values. It could be concluded that variations of the input factors affect the variation of the controlled response and therefore defined regression model is significant. Further analyses could be continued.

Calculated value of Fisher's number $F_{p}$ after conducted ANOVA is 7.5841. Tabular value of this number $F_{t a b}$ has been read from a standard table, depending on level of significance, degrees of freedom and number of replications [10]. Accepted level of significance is $\alpha=0.05$. Value of $F_{t a b}$ is 3.135. It can be concluded that for the analysed study case the following condition has been met:

$$
F_{p}>F_{t a b}
$$

Therefore, null hypothesis is rejected and the regression model and collected data set proved to be significant. Non-conformity error due to residual factors is insignificant and change of controlled output is caused by the controlled variation of input factors. Appropriate DOE design has been used and correct influential factors have been chosen in the planning phase of DOE. Final analysis before accepting the model is in order.

Adequacy analysis of the defined model is the final step in the algorithm of activities of DOE. Fisher's lack-of-fit-test is used to determine whether the defined regression model is a true representation of the process and collected data. Output of this analysis is the significance of non-conformity error. Every regression model has a predicted experimental error $\varepsilon$. This error can be expressed like a mean square error and exists due to two reasons. The first reason is the non-conformity error by residual factors. The significance of this error has proved to be negligible in the previously conducted ANOVA analysis. The second reason is the inadequacy of the defined regression model. A model could be accepted as adequate if and only if mean square error due to model inadequacy has a lower value than mean square error due to effect of residual factors, which had previously been proven to be negligible in ANOVA.

Mean square error due to model lack-of-fit can be calculated by the following expression:

$$
S S_{L o F}=\sum_{i=1}^{n}\left(\bar{y}_{l}-\hat{y}_{i}\right)^{2}
$$

Where is:

$\overline{y_{l}}-$ mean value of the response of $i$ combination of factors,

$\hat{y}_{i}$ - estimated value of the response of $i$ combination of factors.
Mean square error due to effect of residual factors can be calculated by the following expression:

$$
S S_{\text {error }}=\sum_{i=1}^{n}\left(\bar{y}_{l}-y_{i}\right)^{2}
$$

where $y_{i}$ - response of $i$ combination of factors.

Value of Fisher's lack-of-fit number can be calculated by the following expression:

$$
\begin{aligned}
F_{p} & =\frac{\left[\sum_{i=1}^{n}\left(\bar{y}_{l}-\hat{y}_{i}\right)^{2}\right] /(k-2)}{\left[\sum_{i=1}^{n}\left(\bar{y}_{l}-y_{i}\right)^{2}\right] /[k \cdot(n-1)]}= \\
& =\frac{S S_{L o F} /(k-2)}{S S_{\text {error }} /[k \cdot(n-1)]}
\end{aligned}
$$

Tabular value of Fisher's lack-of-fit number could be read from standard tables, depending on the level of significance, degrees of freedom and number of replications of the experiment. Accepted level of significance is $\alpha=0.05$.

If the following expression were to be true:

$$
F_{p}<F_{t a b}
$$

null hypothesis could be accepted and it could be concluded that there is no significant lack-of-fit in the model.

If the following expression were to be true:

$$
F_{p}>F_{t a b}
$$

the null hypothesis would have to be rejected. Therefore, the regression model would not be considered as adequate. There may be some influential factors whose effect had not been taken into account. Changes in the regression model would have to be made.

Calculated value of Fisher's lack-of-fit number is 1.539 , and tabular value of this number is 3.135 [10]. The following condition is fulfilled:

$$
F_{p}<F_{t a b}
$$

and the regression model (4) is accepted as adequate. Using the model, all responses within the specified process window can be calculated.

\section{Nominal values for injection molding production process}

DOE has been completed by fulfilling the validation test and the defined model could be used in solving the main problem of this study case. Nominal values of process parameters could be determined using the defined regression model (4). According to the results (Table 5), it can be concluded that nominal values of the process parameters are the high levels of all four input factors: 


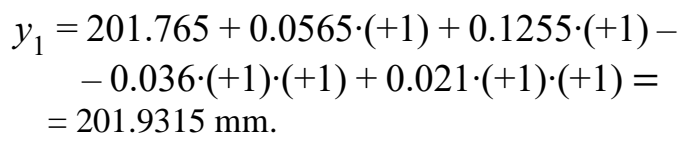

Table 5

\begin{tabular}{lc} 
Nominal values of process parameters \\
\hline \hline Process parameters & Nominal values \\
\hline Die temperature & $90{ }^{\circ} \mathrm{C}$ \\
\hline Injection speed & $100 \mathrm{~cm}^{3} / \mathrm{s}$ \\
\hline Holding pressure & $800 \mathrm{bar}$ \\
\hline Cooling time & $15 \mathrm{~s}$ \\
\hline \hline
\end{tabular}

\section{CONCLUSION}

Nominal values of process parameters of an injection molding process were defined using a DOE methodology. Practical and efficient experiment was one of the purposes of this study case. Nonstandard fractional factorial model with one central point design was chosen in order to meet the basic principles of experimental design, with a minimum number of iterations. Data set was collected and analyzed by statistical methods in order to analytically validate the non-standard design. Firstly, a linear model with second-order interaction members has been created to define the injection process. Only most influential interaction factors were included. Consequently, ANOVA analysis of the model and used data set was conducted. Alternative hypothesis was accepted and concluded that mean values from at least two individual groups differ significantly. In other terms, change of output value is caused by variation of the controlled input factors and the proposed model and collected data are significant. Appropriate DOE design and factors have been chosen in the planning phase of DOE. Finally, adequacy of the regression model was analysed by carrying out Fisher's lack-of-fit-test. Null hypothesis was accepted and the model proved to be adequate. All responses within the specified process window can be calculated using the defined significant and adequate regression model.

Acknowledgment. The authors would like to acknowledge Ph.D. Mikolaj Kuzinovski whose research in the field of DOE had a huge impact on the development of DOE methodology at the institute of Production Engineering and Management, Faculty of Mechanical Engineering, Ss. Cyril and Methodius University in, Skopje, North Macedonia.

Funding. The experimental part of the research was organised and sponsored by the delegation of the
German Economy in Northern Macedonia, Süddeutsche Kunststoff-Zentrum (SKZ) from Würzburg and the company Kostal.

\section{REFERENCES}

[1] MKS Instruments Inc. (2012): The Optimization of Injection Molding Processes Using Design of Experiments [Online]. Available: https://www.mksinst.com/mam/celu m/celum_assets/resources/SenselinkQMDOE-ppNote.pdf

[2] Andrisano, A. O., Gherardini, F., Leali, F., Pellicciari, M., Vergnano, A. (2011): Design of Simulation Experiments method for Injection Molding process optimization, International conference Innov. Meth. Prod. Des., Venice, Italy, 2011, pp. 476-486.

[3] Rajalingam, S., Bono, A., Sulaiman, J. (2012): Determining Optimal Moulding Process Parameters by Two Level Factorial Design with Center Points, J. B. Sri Lankan Journal of Applied Statistics, 11 (1), 63-88, doi: 10.4038/sljastats.v12i0.4968

[4] Abohashima, H. S., Aly, M. F., Mohib, A., Attia, H. A. (2015): Minimization of Defects Percentage in Injection Molding Process using Design of Experiment and Taguchi Approach, Journal of Industrial Engineering and Management, 4 (5), 1-6, doi: 10.4172/2169-0316.1000179

[5] García, V., Sánchez, J. S., Rodríguez-Picón, L. A., Méndez-González, L. C., Ochoa-Domínguez, H. J. (2019): Using regression models for predicting the product quality in a tubing extrusion process. J. Intell. Manuf., 30, 25352544 doi: 10.1007/s10845-018-1418-7

[6] Pan, J. J., Mahmoudi, M. R., Baleanu, D., Maleki, M. (2019): On Comparing and Classifying Several Independent Linear and Non-Linear Regression Models with Symmetric Errors. J. Symmetry, 11 (6), 820-830, doi: 10.3390/sym11060820

[7] Kulkarni, S. (2017): Robust process development and scientific molding, 2nd edition Theory and Practice. Kanser Publications, Cincinnati.

[8] J.J.Faraway (2002): Practical Regression and Anova with $\mathrm{R}$ - Chapman and Hall/CRC

[9] Montgomery D. C., 2013, Design and Analysis of Experiment- 8th Edition, New York, John Wiley \& Sons Inc., 2013, ISBN: 978-1118-14692-7

[10] Kanji, G. K. (2006): 100 Statistical Tests, 3rd Edition, SAGE Publications, London.

[11] Kenyon, G. N. (2015): The Perception of Quality. Springer -Verlag, London.

[12] Montgomery, D. C. (2009): Introduction to Statistical Quality Control 6th Edition. John Wiley \& Sons Inc. Arizona State University.

[13] Attia, U. M., Alcock, J. R. (2010): Optimizing process conditions for multiple quality criteria in micro-injection moulding, The International Journal of Advanced Manufacturing Technology, 50 (5-8), 533-542, doi: 10.1007/s0 0170-010-2547-0

[14] Mitra, A. (2008): Fundamentals of Quality Control and Improvement - $3 \mathrm{rd}$ Edition, New York, John Wiley \& Sons Inc., Chapter 3: "Statistical Process Control”, pp. 263-288. doi: $10.1002 / 9781118491645$ 